\title{
Social Media Use related psychosis in Coronavirus pandemic awareness
}

\author{
Sumati Arikera ${ }^{1}$, Shradha Shejekar ${ }^{2}$, Nayana Naik ${ }^{3}$ \\ ${ }^{1}$ Resident Doctor, \\ ${ }^{2}$ Senior Resident, \\ ${ }^{3}$ Consultant Psychiatrist \\ Institute of Psychiatry and Human Behaviour, Goa. \\ Corresponding author: Sumati Arikera \\ Email - sumati.arikera@gmail.com
}

\begin{abstract}
Presence of evidences of potential therapeutic benefit of using social media is well known, however social media engagement may also be harmful for an individual's mental health and wellbeing. Significant link between social media use and low mood and depression has been reported by several studies. Social media use and low esteem has also been reported. Whereas, it has also been noted that paranoid ideas develop in patients with psychosis after using social media websites. There can also be development of new symptoms and exacerbation of pre-existing symptoms after social media use.

To add to this literature, we report a case of 32 years old male patient with no risk factors, who developed psychosis due to social media use following the pandemic in 2019 (COVID-19)
\end{abstract}

Keywords: COVID-19, social media, psychosis.

$$
\begin{gathered}
\text { (Paper received }-25^{\text {th }} \text { April 2020, Peer review completed }-15^{\text {th }} \text { May 2020) } \\
\text { (Accepted }-19^{\text {th }} \text { May 2020) }
\end{gathered}
$$

\section{INTRODUCTION}

Corona virus pandemic (COVID 19) has created a huge uproar across nations with the beginning of this decade. With the easy accessibility of internet especially in India, social media has left no stones unturned as far as creating awareness among the masses about the virus through various sources like WhatsApp, YouTube, Facebook, Instagram, Twitter, Telegram, Tiktok etc. The estimated mortality rate of the COVID-19 is 3.4\% [1] currently, however, the constant flooding of information across the media has although benefited the public at large, it has also been creating ripples in the mental health of the vulnerable population, who unfortunately, seem to be anticipating a catastrophe by the virus in their lives, with each passing day.

\section{CASE REPORT}

A 32-years old male, studied upto the $10^{\text {th }}$ standard, employed in a garment shop, regular at work, married, was brought on 13/03/2020 with complaints of intense fear that he may be infected with Corona virus, since the past 8 days. Onset was noted after he shook hands with one of his friends, who the next day had developed fever and sore throat. Incidentally patient also developed sore throat in next 2 days, and hence was repeatedly accessing various sources of information over the internet to know more about the Corona virus infection, suspecting that he might have contracted the same through his friend (though the friend was not diagnosed yet). 
Prior to this, patient and his friends had been regularly reading about the pandemic across various social media platforms since last 2 months. Patient gradually started reporting feeling of the virus moving all over his body and preferred exposing himself to sunlight constantly and feared going out in traffic or shaded areas as he read that the virus cannot survive sunlight and that it spreads through air. Also, would feel that crows follow him and thus hint him of his death approaching him soon. Patient would thereafter express fear of dying due to the virus and hence would be found asking for forgiveness from his family members and friends for his past sins. He was also noticed to have disturbed sleep as he felt souls are moving in and out of his body, and walking over his terrace while he is asleep. Patient was reported to be poorly communicative with family members, would mostly remain preoccupied over the last 8 days.

No history of any medical/surgical illnesses was elicited. No past history of psychiatric illness elicited in patient and his first degree relatives. On mental status examination. Patient appeared anxious. Rapport was established with difficulty. Attention was aroused, concentration was ill sustained. Bizarre ideas that crows follow him and thus hint about his death approaching and souls moving in and out of his body and on his terrace was elicited (Cultural aspect of same was ruled out). Ideas of black magic by unknown source that it is caused by someone was also elicited.

Also noted was tactile hallucination of corona virus moving over his body. Clinically, his intelligence appeared average. He was oriented to time, place and person. Insight appeared grade 3. No significant physical/ neurological examination findings were found. Routine blood investigations and CT brain were normal. He tested COVID negative. Based on history the patient was diagnosed as Acute and transient psychotic disorder with symptoms of schizophrenia, with associated acute stress, according to International Classification of Diseases - 10; and started on Risperidone $2 \mathrm{mg}$ in view of psychotic symptoms. Clonazepam was given in divided doses throughout the day, to allay the anxiety.

Within 4 weeks of initiating Tab. Risperidone, patient reported minimal improvement in his symptoms in terms of reduced tactile hallucinations, reduced fearfulness. Fear of having contracted Corona virus infection had subsided. Anxiety had reduced, however bizarre ideas and ideas of black magic persisted.

\section{DISCUSSION}

Social media use (SMU) and its impact on mental health has been always debatable. While there are studies which claim that emotional involvement in social media use can lead to depression and anxiety [2], there are some studies which show no negative impact on mental health of the user [3]. There are reports of high paranoia caused by posting and venting feeling on social media but not by social media use [4]. While there are significant number of studies on SMU causing depression/anxiety, the data on SMU causing psychosis is sparse [5].

We conclude that, usage of social media is a responsibility. Considering the immense impact it has on mental health, creating awareness on safe utilization, reception, acceptance and assimilation of social media data is important before overwhelming the population to a plethora of information through it.

Possible stressors for this patient to develop psychosis could be fear of infection due to the virus and also probably inadequate information regarding the virus. Steps that may be undertaken to prevent individuals develop psychosis or any other mental health issues during the times of pandemic.

- Provide as much as information possible regarding the causative agent, preventive measures, its symptoms and availability of health care facilities to treat such symptoms.

- Assurance to the individuals/patients that they could stay safe if preventive methods are followed adequately.

- Usually patients develop anxiety, depression, insomnia, suicidal tendencies which should be tackled with utmost care to prevent worsening of mental health issues.

\section{REFERENCES}

1. Global research on coronavirus disease (COVID-19) [Internet]. [cited 2020 Mar 15]. Available from: https://www.who.int/emergencies/diseases/novel- coronavirus-2019/global-research-on-novel-coronavirus2019-ncov 
2. Pettijohn TF II, La Piene KE Pettijohn TF, Horting AL. Relationships between Facebook intensity, friendship contingent self-esteem, and personality in US college students. Cyberpsychology 2012;61-7.

3. Primack BA, Shensa A, Escobar-Viera CG, Barrett EL, Sidani JE, Colditz JB, James AE. Use of multiple social media platforms and symptoms of depression and anxiety: A nationally-representative study among US young adults. Comp Hum Behav 2017;69:1-9.

4. Berry N, Emsley R, Lobban F, Bucci S. Social media and its relationship with mood, self- esteem and paranoia in psychosis. Acta Psychiatr Scand 2018;138(6):558-70.

5. Nitzan U, Shoshan E, Lev-Ran S, Fennig S. Internet-related psychosis-a sign of the times. Isr J Psychiatry Relat Sci 2011;48(3):207-11.

$\star * * * * * * * * * * * * * * * * * * * * * * * * * * * * * * * * * * *$

\section{Acknowledgements - Nil \\ Conflict of Interest $-\mathrm{Nil}$ \\ Funding - Nil}

